УДК $378: 373$

DOI:

Борис Савчук, доктор історичних наук, професор кафедри педагогіки імені Б. Ступарика Прикарпатського національного університету імені Василя Стефаника Галина Білавич, доктор педагогічних наук, професор кафедри педагогіки початкової освіти Прикарпатського начіонального університету імені Василя Стефаника Ольга Валігунда, студентка Прикарпатського національного університету імені Василя Стефаника

\title{
ПРОБЛЕМА ПРОФЕСІЙНОЇ ПІДГОТОВКИ МАЙБУТНІХ УЧИТЕЛІВ ДО ДІАГНОСТИКИ ПЕДАГОГІЧНОГО СУПРОВОДУ В КОНТЕКСТІ СУЧАСНОГО НАУКОВОГО ДИСКУРСУ
}

У статті здійснено аналіз наукового дискурсу проблеми професійної підготовки майбутніх учителів до діагностики педагогічного супроводу навчального проиесу. На основі аналізу базових нормативних документів та сукупності наукових досліджень визначено основні підходи і тлумачення понять $і$ категорій "професійна підготовка майбутніх педагогів", “діагностика”, “педагогічна діагностика”, "педагогічне діагностування”, “супровід”, “педагогічна підтримка”. Запропоновано визначення поняття "професійна підготовка майбутніх учителів до діагностики педагогічного супроводу”, схарактеризовано ії основні складники.

Ключові слова: професійна підготовка майбутніх педагогів; діагностика; педагогічна діагностика; супровід; педагогічна підтримка.

תim. 7.

Borys Savchuk, Ph.D.(History), Professor of the Department of Pedagogy named after Bohdan Stuparyk, Vasyl Stefanyk Precarpathian National University Halyna Bilavych, Ph.D.(Pedagogy), Professor of the Pedagogy of Primary Education Department Vasyl Stefanyk Precarpathian National University Olha Valihunda, Student of Vasyl Stefanyk Precarpathian National University

\section{THE PROBLEM OF THE PROFESSIONAL TRAINING OF FUTURE TEACHERS FOR THE DIAGNOSTICS OF PEDAGOGICAL SUPPORT IN THE CONTEXT OF MODERN SCIENTIFIC DISCOURSE}

The article elucidates peculiarities of professional training of teacher. It shows the directions, components and essence of modern requirements to professional training of teacher. Emphasis is placed on the main factors of new approaches to preparing the prospective teachers. The article presents compressed analysis of scientific and pedagogical literature on professional training of future teachers; analyzes the concept "professional training of future teacher".

The article proves the necessity to adapt curriculum and pedagogical support of students into higher education, which is defined by its methodological techniques and principles. Besides it analyzes the modern psycho-educational approaches to teaching support. The article presents the interpretation of the concept "accompaniment", also the correlation of the different areas of scientific knowledge in the definition of this notion is emphasized: pedagogy, psychology, social pedagogy, sociology. The author discloses the purpose and function of pedagogical accompaniment of the educational process, kinds of pedagogical influence on the accompanied object are characterized. In particular, the realization algorithm of pedagogical accompaniment of the educational process is worked out.

Also, we determined the level of professional competence of teachers. Psycho-pedagogical support of the above categories of professional competence of teachers we examined through the mechanisms of self personality of the teacher. Its main objectives are defined as follows: self-development motivation professional competence on the basis of changes in his relationship to his professional activities, and the formation of positive personal and professional self-concept, and the creation of alternative models and programs for the development of professional competence, stimulation self-projection of self-development of professional competence. This paper reviews educational testing, its nature and content. It covers the importance of knowledge of these aspects as a basis for diagnostic support educational activities of primary school teachers, that is an opportunity to improve the educational process and to determine individual characteristics of students more carefully.

Keywords: maintenance; support; help; professional training; professional training of future teachers; educational support; training adaptation; a student; diagnostic activities of primary school teachers; diagnostic support.

$\Pi$

остановка проблеми. За умов реформування системи освіти в Україні таїї інтеграції у європейський

освітній простір ускладнюються вимоги до професійної діяльності педагога. Однім із виявів цього $є$ потреба вдосконалення підготовки 
майбутніх фахівців до діагностичної діяльності, адже випускник ЗВО має бути обізнаним із теоретичними засадами і методикою отримання очікуваних результатів навчання, виховання i розвитку учнів різних вікових категорій. Тому проблема діагностичного супроводу актуалізується в педагогічній теорії і освітній практиці та стає однією 3 пріоритетних у професійній педагогіці вищої школи.

Визначення науково-теоретичних засад діяльності в цьому напрямі потребує всебічного аналізу в контексті сучасного педагогічного дискурсу проблеми категорійно-поняттєвого апарату діагностичної діяльності педагогів, зокрема в ракурсі підготовки до її здійснення майбутніх учителів. Наріжні методологічні орієнтири розв'язання цієї проблеми дають положення базових освітніх документів: Національна стратегія розвитку освіти України на період до 2021 року (2013), Закон України "Про освіту” (2017), Закон України “Про вищу освіту” (2014), Концепція нової української школи (2016), Державний стандарт початкової освіти (2018) та ін.

Аналіз наукових досліджень. Комплекс проблем, що стосуються теорії і практики професійної підготовки майбутніх педагогів у 3ВО, розглядається у значному доробку українських і зарубіжних авторів (О. Абдулліна, Ю. Бабанський, В. Бондар, Н. Волкова, С. Гончаренко, О.Дубасенюк,В.Загвязинський,І.Зязюн,Т.Левовицький, Н. Ничкало, С. Сисоєва, В. Сластьонін,В. Сухомлинська та ін.). Учені всебічно обгрунтували мету, зміст, завдання, структуру, інші компоненти вищої педагогічної освіти та системи підготовки майбутніх учителів. Проблема діагностичної діяльності в рамках педагогічної науки переважно розробляється в контексті її проведення вчителями та професійної підготовки студентів до їі здійснення (Г. Андрєєва, О. Андрієнко, О. Баранова, В. Бербец, В.Бондар,М.Боритко,Г.Гац,М.Гермогенова, А. Григор'єв, І. Дичківська, В. Завіна, Л. Кравченко, О. Кочетов, Н. Краснова, Н. Кузьміна, Т. Купріянчик, С. Мартиненко, І. Новик, О. Третяк, та ін.). Нагромаджений масив літератури окреслює широкий спектр тлумачень означених та інших проблем, що актуалізує його розгляд крізь призму наукового дискурсу.

Мета статті полягає у здійсненні аналізу наукового дискурсу питання професійної підготовки майбутніх учителів до діагностики педагогічного супроводу. Її реалізація передбачає визначення основних підходів і тлумачень пов'язаних із нею понять і категорій та з'ясування здобутків і вузьких місць у вивченні цієї проблематики задля вдосконалення її подальшої розробки.
Виклад основного матеріалу. Дефініціювання проблеми професійної підготовки майбутніх педагогів має глибоку багатолітню традицію. Основним орієнтиром для ії осмислення слугують нормативні документи (Національна рамка кваліфікацій (2011), Закон України "Про вищу освіту” (2014), Закони України “Про освіту” (1996, 2017) та ін.), які, спираючись на європейський досвід, трактують професійну підготовку як “здобуття кваліфікації за відповідним напрямом підготовки або спеціальністю”, тобто у проекції фахової, профільної підготовки, спрямованої на кінцевий результат.

Ця базова проекція зберігається і в наукових студіях, де проблема розглядається в широкому спектрі дефінітивних трактувань. Попри розмаїття наукових рефлексій, відстежується домінуюча тенденція, згідно з якою професійна підготовка майбутніх учителів визначається з акцентуванням на тому, що це $\epsilon$ цілеспрямований, організований, систематичний, творчий процес формування комплексу особистісно-професійних якостей, що стосуються професійних знань, умінь, навичок та загальної, професійної і фахової компетентності, які мають бути вироблені в освітньому процесі ЗВО з урахуванням профілю, спеціальності і спеціалізації майбутніх фахівців.

Проблема діагностичної діяльності на науковометодологічному рівні в українській педагогічній науці актуалізувалося наприкінці ХХ ст. На рівні державної освітньої політики чи не вперше вона була чітко виокремлена i увиразнена в Національній стратегії розвитку освіти в Україні на період до 2021 року (2013). Документ спрямовує на перебудову навчально-виховного процесу на засадах розвивальної і експериментальної педагогіки, що передбачає виявлення та розкриття потенціалу і здібностей

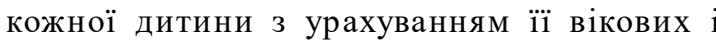
психологічних особливостей. Тому для якісного прориву в розвитку національної системи загальної середньої освіти необхідно забезпечити розробку методик раннього виявлення нахилів, здібностей і інтересів учнів засобами діагностики [6].

Науково-педагогічний дискурс уцьому напрямі розгортається на міждисциплінарному рівні через запозичення досвіду різних галузей знань.

Передусім ідеться про поняття "діагностика" (грец. здатність розпізнавати), яке є стрижневим у медицині (передбачає комплекс заходів, обстежень із встановлення причини захворювання, змін в організмі тощо для призначення ефективного лікування). Ним активно оперують у соціології, де розуміння діагностики має найбільш універсальний характер, адже в 


\section{ПРОБЛЕМАПРОФЕСІЙНОЇПІДГОТОВКИМАЙБУТНІХ УЧИТЕЛІВ ДО ДІАГНОСТИКИ ПЕДАГОГІЧНОГО СУПРОВОДУ В КОНТЕКСТІ СУЧАСНОГО НАУКОВОГО ДИСКУРСУ}

цьому випадку вона передбачає зібрання, обробку, аналіз широкого спектру даних про становище у соціальній сфері країни, життєдіяльність різних соціальних груп тощо.

У ракурсі досліджуваної проблеми особливе значення має доробок психологічної науки, 3 позицій якої мета діагностики полягає у визначенні особливостей психічного розвитку дитини і дорослого, сформованості їхніх психологічних якостей, відповідності рівня розвитку умінь, навичок, особистісних якостей віковим нормам і професійним вимогам; виявленні психологічних причин труднощів у навчанні і вихованні та професійній діяльності. Ця мета конкретизується через категорію “психодіагностика”, зміст ізавдання якоїполягають в отриманні шляхом використання спеціального наукового інструментарію інформації про індивідуальнопсихологічні особливості дитини і дорослого, корисної для них самих і тих, хто з ними працює. На цій основі здійснюється психологічна корекція, тобто робота з усунення відхилень у психічному розвитку, що перешкоджають формуванню особистості; програми її реалізації здійснюються педагогами у шкільних колективах та фахівцями у відповідних соціальних групах.

Освітня практика передбачає комплексне застосування психодіагностики: практикуючі психологи визначають індивідуально-психологічні особливості учня, студента, а вчителі, науковопедагогічні працівники на цій основі виявляють їхній вплив на результати навчання, виховання i розвитку. Психологічна і педагогічна діагностики тісно пов'язані, але виконують різні функції: перша спрямована на оцінювання основних психофізіологічних складників особистості; друга

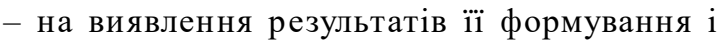
розвитку та їхнє використання для вдосконалення педагогічного процесу. Така загалом сконсолідована позиція випливає з доробку вченихпсихологів (Т. Артемова, І. Бех, М. Бітянова, О. Бодалев, А. Григор'єв, Ю. Гільбух, Г. Карпова та ін.) і педагогів (Б. Бітінас, М. Боритко, М. Гермогенова, С. Гіляревський, М. Голубєв, І. Гутник, О. Дорофеєва, О. Кочетов, С. Мартиненко, І. Новик, В. Царьков та ін.).

Отже, як міждисциплінарна галузь знань діагностика покликана розробляти теорію i практику організації процесу постановки діагнозу для визначення стану об'єкта пізнання і оцінювання та заходів, спрямованих на усунення перешкод його розвитку, визначення шляхів і способів його ефективного формування, функціонування. Таке загальне розуміння цього феномену зумовлює широкий спектр його трактування в педагогіці та відсутність сконсолідованої позиції з цього приводу.

Вважається, що поняття "педагогічна діагностика" вперше застосував у 1968 р. німецький учений К. Інгенкамп. У його класичній праці з такою ж назвою було визначено основні предмет і завдання цього наукового напряму, які полягають в обгрунтуванні принципів і методів розпізнавання і встановлення ознак, що характеризують нормальний або 3 відхилом від норм перебіг педагогічного процесу та визначають методи і засоби встановлення діагнозу. Учений акцентував на подібності педагогічної діагностики з психодіагностикою, які покликані вивчати властивості, здібності, рівень когнітивного розвитку особистості [4].

Упродовж півстоліття педагогічна діагностика сформувалася в окрему субдисципліну, яку виправдано розглядають як підрозділ педагогіки, хоча іноді в такому ж статусі їі відносять до психології. Вона має міждисциплінарний характер та охоплює основні складники навчальновиховного процесу: від вивчення окремої особистості, групи та шкільного колективу до оцінювання основних аспектів навчальної і виховної діяльності та системи управління освітою загалом. За сучасних умов діагностика стала важливим інструментом функціонування всіх типів дошкільних, навчальних, позашкільних i управлінських установ і закладів, що зумовлює їі особливості в усіх сферах застосування.

Аналіз літератури 3 теорії педагогіки i спеціальних праць $з$ педагогічної діагностики показав, що серед науковців, з одного боку, виробилася спільна сконсолідована лінія щодо розуміння цього феномену, з іншого, існують важливі відмінності в трактуванні його сутності і характеру. Це передусім стосується дефініціювання родового поняття “діагностика”. Утвердилося загальне розуміння того, що воно $є$ ширшим і має глибший зміст, ніж поняття “контроль” (за знаннями і вміннями тощо), яке відображає результати навчання, але не пояснює їхні причинно-наслідкові зв'язки.

У загальному сенсі в теорії і практиці педагогіки категорія “діагностика” розглядається як отримання інформації про стан і розвиток контрольованого об'єкта, його відхилення від норми. При цьому в одному випадку воно трактується як процес отримання об'єктивної інформації про стан і розвиток досліджуваних об’єкта або суб'єкта (див., напр.: С. Мартиненко [5]), в іншому - як засіб проникнення в педагогічну ситуацію для отримання реальних уявлень про його стан і розвиток (І. Підласий $[7,15])$. 


\section{ПРОБЛЕМАПРОФЕСІЙНОӤПІДГОТОВКИМАЙБУТНІХ УЧИТЕЛІВ ДО ДІАГНОСТИКИ}

ПЕДАГОГІЧНОГО СУПРОВОДУ В КОНТЕКСТІ СУЧАСНОГО НАУКОВОГО ДИСКУРСУ

Вважаємо, що всі означені підходи мають сенс, тож, інтегруючи їх, педагогічне діагностування можемо розглядати як спосіб, метод і процес отримання за допомогою спеціальних методик i інструментарію різнобічних даних про стан об'єкта (суб'єкта) та відхилення в його розвитку 3 метою визначення шляхів і можливостей їхнього усунення для вдосконалення і покращення його подальшого розвитку.

3 аналізу сучасного наукового дискурсу, представленого у доробку згадуваних та інших авторів, випливають дві важливі характеристики педагогічного діагностування, які дозволяють зіставити ㄲï із соціальною діагностикою i психодіагностою. Перша, загальна і апріорі притаманна усім науковим дисциплінам, що займаються цією справою, полягає в тому, що діагностика є особливим видом дослідження (пізнання), який здійснюється зі застосуванням спеціальних, розроблених педагогічною наукою, методів і прийомів задля виявлення внутрішнього стану та можливих відхилень від норм і труднощів розвитку об' єкта або суб'єкта освітнього процесу для визначення необхідних корекційних дій, заходів, які мають забезпечити усунення перешкод і оптимізувати шляхи, потенційні можливості для цілісного розвитку особистості.

Суттєве значення для розуміння феномену педагогічної діагностики має її важлива особливість, яка полягає в тому, що вона апріорі не ставить за мету отримання принципово нових науково-педагогічних знань, позаяк спрямована не на з'ясування непізнаних закономірностей, а на виявлення в кожному конкретному випадку стану педагогічної ситуації або їі об'єктів, суб'єктів, визначення причин і характеру відхилень у їхьому розвитку для ухвалення відповідних рішень, заходів з їхнього усунення, корекції тощо $[5,13])$.

Як показав аналіз, у сучасних науковопедагогічних дослідженнях також існує доволі широкий спектр поглядів і підходів до трактування поняття “супровід”. Залежно від предмета і завдань теоретичного або експериментального дослідження воно розглядається як “метод”, “процес" “служба супроводу” або навіть як “умови” i “система” педагогічної діяльності тощо. 3 таких позицій здійснюється його класифікації, структуризація і характеристика (I. Бех, М. Бітянова, I. Дичківська, В. Гриценко, Г. Карпова, В. Зінченко, С. Мартиненко, О. Мельник, М. Мруга, І. Новик, О. Омельченко, І. Підласий, О. Савченко та ін.).

3 розмаїття категорізації поняття "супровід" (“педагогічний супровід”) продуктивними i перспективним виглядають п’ять визначених нами умовно-основних взаємопов'язаних підходів до його розуміння. Перший стосується трактування супроводу як цілісної, системно організованої діяльності зі створення соціальнопсихологічних i педагогічних умов для продуктивної організації освітнього процесу та керівництва і управляння ним, з одного боку, та самореалізації його учасників (як учня, студента, так і вчителя, викладача, адміністратора тощо), з іншого.

Прихильники другого підходу акцентують на ролі і завданнях педагога як організатора процесу педагогічного супроводу. У такому ключі він розглядається як “спеціальна" діяльність або як “різновид” педагогічної (професійної) діяльності, що спрямована на вивчення стану об'єктів (суб'єктів) навчання і виховання для ефективного управління цим процесом та оптимізації взаємодії вчителя й учня. Це вимагає володіння педагогом спеціальними знаннями і вміннями пізнати дитину, починаючи від іiі індивідуальних особливостей, можливостей, потреб тощо й завершуючи перспективами особистісного зростання.

Прибічники третього, умовно визначеного підходу, фокусують на домінанті технологічного призначення супроводу, що становить систему процедур, методик і методів та технологій і засобів для виявлення умов i чинників функціонування педагогічних об'єктів та перебігу педагогічних процесів для 3’ясування їхнього стану і ефективності. Цей “технологічний підхід” конкретизує розуміння супроводу як методу і способу його практичного здійснення та створення умов 3 ухвалення учасниками освітнього процесу оптимальних рішень під час педагогічної взаємодії і за різних ситуацій життєвого вибору.

Четвертий, умовно визначений як “інтегративний”, підхід у різних варіантах акумулює окреслені й інші аспекти феномену педагогічного дискурсу. У такому сенсі він розглядається як спільна професійна діяльність суб' єктів у напрямі опанування новим змістом та технологіями навчання і виховання учнів; як процес і сукупність послідовних дій, що забезпечує системну професійну діяльність психологів і педагогів, які його здійснюють, та дозволяє дитині задовольнити і реалізувати свої особисті здібності й пізнавальні інтереси.

Зважаючи на сучасні освітні пріоритети, які відображають парадигми особистісно орієнтованого і діалогічного “суб”'єкт-суб' єктного” навчання, вважаємо, що педагогічний супровід не повинен зводитися лише до створення спеціальних умов для педагога, а має передусім 


\section{ПРОБЛЕМАПРОФЕСІЙНОӤПІДГОТОВКИМАЙБУТНІХ УЧИТЕЛІВ ДО ДІАГНОСТИКИ ПЕДАГОГІЧНОГО СУПРОВОДУ В КОНТЕКСТІ СУЧАСНОГО НАУКОВОГО ДИСКУРСУ}

передбачати й орієнтувати на надання допомоги учням. 3 таких позицій перспективним видається п’ятий визначений нами підхід, згідно $з$ яким педагогічний супровід розглядається як близький до поняття "підтримка".

Одним із перших поняття “педагогічна підтримка” до наукового обігу ввів О. Газман (1995), який розумів під ним процес спільної праці тих, “хто навчається”, з тими, “хто навчає”, для визначення цілей, можливостей і шляхів розв'язання проблем і подолання перешкод, які заважають розвитку особистості вихованця та самостійного досягнення ним бажаних результатів у навчанні, самовихованні, спілкуванні, способі життя [2]. У процесі подальшого розвитку педагогічну підтримку стали розглядати як надання допомоги дітям у розв'язанні їхніх проблем за умов навчального закладу для їхньої успішної соціалізації.

Виходячи з розуміння близькості феноменів “супровід” i “підтримка”, та акумулюючи доробок учених психологів і педагогів (І. Валітова, В. Зінчеоко, Е. Зеєр, І. Мамайчук та ін.), І. Дичківська показала, що "супровід включає в себе підтримку”, а “підтримка означає надання допомоги у вигляді системи заходів”. Їхня реалізація має на меті “принести комусь полегшення в чомусь”. Таким чином, у розумінні вченої супровід означає не лише створення умов, які сприяють формуванню особистості дитини, але й надання допомоги з розробки індивідуальної програми її розвитку і навчання. Отже, супровід включає в себе і підтримку, і допомогу $[3,7]$.

3 означених вище позицій продуктивною видається позиція ученого I. Беха, який пов'язав психологічний супровід із особистісно орієнтованою моделлю виховання. Вона передбачає залучення учня до взаємодії 3 довкіллям як основи формування його “ціннісних ставлень”, що відповідають позиціям сучасної культури. "Центральним ядром" психологічного супроводу науковець вважає конструктивну і гуманістично спрямовану взаємодію, а тї “центральним механізмом" - особистісне спілкування педагога 3 вихованцем, яке орієнтоване на зближення їхніх смислових цінностей $[1,10]$.

Висновки та перспективи подальших досліджень. Отже, інтегруючи означені вище підходи і трактування, з позицій сучасного науково-педагогічного дискурсу професійну підготовку майбутніх учителів до діагностики педагогічного супроводу можемо визначити як цілеспрямований, системно-організований процес 3 формування у майбутніх педагогів загальних, професійно-фахових компетентностей, що мають забезпечити використання діагностичного супроводу як ефективного інструменту визначення стану, рівня, відхилень від норми різних компонентів навчально-виховного процесу для визначення шляхів i можливостей його корегування, вдосконалення, прогнозування результатів шляхом створення для цього сприятливих умов. Унаслідок цього в них має сформуватися чітке розуміння феномену діагностичного супроводу як ефективного науково-дослідного інструментарію, що складається зі сукупності методів, прийомів і засобів, спрямованих на виявлення стану розвитку пізнавальних можливостей учнів та особистісно орієнтованого, гуманістично-ціннісного процесу, що має забезпечити реалізацію індивідуальних потреб, інтересів дитини, допомогти їй у розкритті природних здібностей і розвитку творчого потенціалу. Подальших досліджень потребує вивчення порушеної у статті проблеми в контексті європейського наукового дискурсу.

\section{ЛІТЕРАТУРА}

1. Бех І. Психологічний супровід особистісно орієнтованого виховання. Початкова школа. 2003. №3. C. 3-6.

2. Газман О. С. Педагогическая поддержка детей в образовании как инновационная проблема. Новые ценности образования: десять концепций и эссе. Вып. 3. Москва, 1995. С. 58-63.

3. Дичківська І. Д Теоретико-методичні проблеми психолого-педагогічного супроводу діяльності вихователя інклюзивної групи. Наукові записки Рівнен. держ. гуманітар. ун-ту. 2014. Вип. 10. С. 6-11.

4. Ингенкамп К. Педагогическая диагностика / Пер. с нем. Москва, 1991. 240 с.

5. Мартиненко С. М. Діагностування особистіснопрофесійних якостей вчителя початкової школи. Навч.метод. посіб. Київ, 2015.208 с.

6. Національна стратегія розвитку освіти в Україні на період до 2021 року. Затверджена указом Президента України від 25.06.13 p. URL: http://zakon3.rada.gov.ua/ laws/show/344/2013.

7. Підласий I. П. Діагностика та експертиза педагогічних проектів. Навч. посіб. Київ, 1998. 343 с.

\section{REFERENCES}

1. Bekh, I. (2003). Psykholohichnyi suprovid osobystisno oriientovanoho vykhovannia [Psychological support of personally oriented education]. Primary school. No. 3, pp. 3-6. [in Ukrainian].

2. Hazman, O. S. (1995). Pedahohicheskaia podderzhka detei v obrazovanii kak innovatsyonnaia problema [Pedagogical support of children in education as an innovative problem]. New values of education: ten concepts in the essay. Vol. 3. Moskow, pp. 58-63. [in Russian]. 


\section{РОЗВИТОК ШКІЛЬНОЇ БІОЛОГІЧНОЇ ОСВІТИ В УКРАЇНІ \\ У 80-90-ТІ РОКИ ХХ СТ. (історіографія проб̆леми)}

3. Dychkivska, I. D. (2014). Teoretyko-metodychni problemy psykholoho-pedahohichnoho suprovodu diialnosti vykhovatelia inkliuzyvnoi hrupy [Theoretical and methodological problems of psychological and pedagogical support of the activity of the educator of an inclusive group]. Scientific notes of Rivnens. State Humanist University. Vol. 10, pp. 611. [in Ukrainian].

4. Inhenkamp, K. (1991). Pedahohicheskaja diahnostika [Pedagogical diagnostics]. Moskow, 240 p. [in Russian].

5. Martynenko, S. M. (2015). Diahnostuvannia osobystisno-profesiinykh yakostei vchytelia pochatkovoi shkoly. Navch.-metod. posib. [Diagnosis of personality and professional qualities elementary school teacher]. Kyiv, 208 p. [in Ukrainian].

6. Natsionalna stratehiia rozvytku osvity v Ukraini na period do 2021 roku. Zatverdzhena ukazom Prezydenta Ukrainy vid 25.06.13 r. [The National Strategy for the Development of Education in Ukraine until 2021. Approved by the Decree of the President of Ukraine dated June 25. 13. 2013]. Available at: http://zakon3.rada.gov.ua/laws/ show/344/2013. [in Ukrainian].

7. Pidlasyi, I. P. (1998). Diahnostyka ta ekspertyza pedahohichnykh proektiv [Diagnostics and expertise of pedagogical projects]. Kyiv, 343 p. [in Ukrainian].

Стаття надійшла до редакції 15.03.2019

УДК 37.01:57(477)

DOI:

Марія Чепіль, доктор педагогічних наук, професор, завідувач кафедри загальної педагогіки та дошкільної освіти Дрогобицького державного педагогічного університету імені Івана Франка

\section{РОЗВИТОК ШКІЛЬНОЇ БІОЛОГІЧНОЇ ОСВІТИ В УКРАЇНІ У 80 - 90-ТІ РОКИ ХХ СТ. (історіографія проблеми)}

У статті висвітлено розвиток шкільної біологічної освіти в Україні упродовж 80-90-х рр. ХХ ст. Розкрито зміст реформ шкільної освіти, появу предмета “Біологія", дезнайшли відображення ідеї системного підходу, реалізація змістового потенціалу курсу біології для профорієнтації учнів. Виявлено низку суперечностей у розвитку шкільної біологічної освіти. Акиентовано увагу на вимогах до змісту підвищення кваліфікації педагогічних кадрів, розвитку системи підвищення кваліфікації педагогічних кадрів.

Ключові слова: освіта; реформи освіти; шкільна біологічна освіта; історіографія; учитель біології; суперечності; Україна.

Jim. 7.

Mariya Chepil, Doctor of Education, Professor, Head of the General Pedagogy and Preschool Education Department, Drohobych Ivan Franko State Pedagogical University

\section{DEVELOPMENT OF SCHOOL BIOLOGICAL EDUCATION IN UKRAINE IN THE 80'S AND 90'S OF THE XXTH CENTURY (historiography of the problem)}

The features of school biological education in Ukraine, whose development took place in the context of socio-political, socio-economic determinants during the studied period was identified. Significant for school biological education were 80 - 90-ies of the XXth century. The provisions of the concept of secondary biological education, created in the early 80's of the XXth century were the basis of the "Programs for the Secondary School of Biology" (1986).

Beginning of democratic transformations contributed to the development of the system of school biological education: intensified the search for optimal ways to update the content, taking into account the scientific research in science and teaching methods; the study of foreign experience and the introduction of its elements into the practice of the work of educational institutions; the revival of the spirituality of the Ukrainian school; increasing the professional skills of biology teachers by expanding and deepening democratic foundations in the organization of postgraduate education of teachers.

The content of school education reforms, the emergence of the subject "Biology", which reflected the idea of a systematic approach, the implementation of the content potential of the biology course for guidance students. A number of contradictions in the development of school biological education have been identified. The emphasis is placed on the requirements for the content of the training of pedagogical staff, the development of the system for improving skills of teaching staff.

Negative trends were observed: extensive school development; centralization of management as a consequence of the continuous influence of mono-ideological policy on the state of education; neglect of the national idea and its leveling in the reformation of school biological education; strengthening the ideological influence on the content 